\title{
РЕТРОСПЕКТИВНИЙ АНАЛІЗ ТА ПЕРСПЕКТИВИ ФУНКЦІОНУВАННЯ СВІТОВОГО РИНКУ ЗОЛОТА
}

\author{
Ксенжук Олександр Степанович \\ здобувач \\ Тернопільський національний економічний університет (м. Тернопіль, Україна) \\ ksend-a@ukr.net
}

\begin{abstract}
У статті подана характеристика ролі золота в історичній перспективі та сьогоденні. Золото втратило роль грошей і перетворилося на товар. Фізико-хімічні властивості золота зумовлюють незмінно високий рівень інвестиційної привабливості. Виявлено, що динаміка розвитку ринку золота за останні десятиліття демонструє висхідну тенденцію. Перманентно зростає частка країн, що розвиваються, у формування світового попиту на золото. Причиною надання золоту пріоритету як засобу нагромадження та зберігання вартості є зростання ризиковості глобального економічного простору враховуючи зростаючу взаємозалежність країн внаслідок глобалізаційних процесів. Ювелірна галузь демонструє зростання попиту на ювелірні вироби. Зростання попиту на золото як на інструмент хеджування і збереження вартості, а також розвиток ювелірної галузі обумовлюють висхідні тенденції видобутку золота, а отже і розвитку ринку золота.
\end{abstract}

Ключові слова: ринок золота, інвестиційна привабливість, золоті резерви, видобуток золота, дорогоцінні метали. DOI: https://doi.org/10.32845/bsnau.2019.2.17

\section{Постановка проблеми}

Золото пройшло тривалу еволюцію, багаторазово змінюючи свої функції і роль в світовій економіці, проте, на всіх етапах розвитку цивілізації ця роль залишалася високою. Золото $€$ найважливішим елементом світової фінансової системи, оскільки даний метал не схильний до корозії, має багато сфер технічного застосування, а запаси його невеликі. У всі часи світової економічної системи, золото було невід'ємною частиною економічних відносин. У сучасних умовах золото перестало бути основою грошового обігу, але є складовою частиною золотовалютних резервів країн. Виходячи 3 цього, питання організації та ефективного функціонування ринку золота нині користується актуальністю.

\section{Аналіз останніх досліджень і публікацій}

Динаміка розвитку ринку золота зберігає висхідний тренд за останні десятиліття внаслідок посилення глобалізаційних та інтеграційних процесів [1]. Поряд із зростанням попиту на дорогоцінні прикраси (45\% видобутого золото припадає на ювелірну галузь), золото активно набуває роль надійного об'єкта для інвестування (інвестиції у золото становлять $30 \%$ від обсягу видобутку) [1; 2]. Значної ваги золоту як засобу нагромадження та зберігання вартості надають економіки, що розвиваються: світовий попит на золото в останні десятиліття детермінується цими країнами [3; 4]. Проте, необхідно деталізувати особливості організації ринку золота для забезпечення ефективного його функціонування з огляду на структурні зрушення у глобальному просторі.

Цілі статті

У статті поставлені такі цілі:

- дати характеристику ролі золота в історичній перспективі та сьогоденні

- здійснити аналіз сучасних тенденцій ринку золота

- виокремити перспективи розвитку ринку золота

Основний текст

Активний розвиток грошово-кредитних інститутів i, перш за все, зростання емісії паперових грошей підірвали основи золотого стандарту. Спостерігалася активізація процесу демонетизації золота й обмеження ролі золота як міжнародних грошей, оскільки міжнародна торгівля золотом піддалася посиленим державним інтервенціям обмежувального характеру.

Наявність запасів золота як високоліквідного ресурсу, який володіє інвестиційної цінністю, дозволяє розраховувати на фінансування потреб держави, заходів по ліквідації надзвичайних ситуацій у разі недостатності коштів з інших джерел.

Природні властивості золота послужили підставою для того, щоб воно виділилося з усього розмаїття товарів і стало застосовуватися в якості загальної міри вартості - загального еквівалента. Золото виявилося найкращим товаром для виконання ролі грошей. Його особливості як, наприклад, легка фізична подільність, вільне перетворення без втрати вартості з монетної форми в злитки, прикраси, а також портативність, довговічність і рідкісність надали цьому дорогоцінному металу роль грошей.

Протягом декількох тисячоліть золото виконувало роль грошей і найбільш поширеного засобу збереження заощаджень. Золоті монети з'явилися на заході правління короля Лідії Кроезуса приблизно 550 років до н.е [1]. У Китаї золоті монети Ін Юаня з'явилися приблизно в той же час [2]. Золоті монети були в обігу багато століть. Оскільки вони були невід'ємними елементами для повсякденних операцій, срібло також відігравало важливу роль для багатьох країн.

Ставлення до золота як платіжного засобу, засобу вартості і нагромадження скарбів з плином часу сильно змінилося. Так, Дж. М. Кейнс під час свого виступу перед Палатою лордів 23 травня 1944 р. визначив золото як джерело всіх бід і чвар людства, пережиток варварства [3].

В економічному сенсі золото пройшло ряд утворень в результаті яких змінило функції в умовах розвитку економік світу. Сутність золота проявляється в його функціях. Існують різні трактування цих функцій в залежності від досліджень. Тим не менше, у глобальній економіці золото виконує ряд суспільних функцій (рис. 1). 


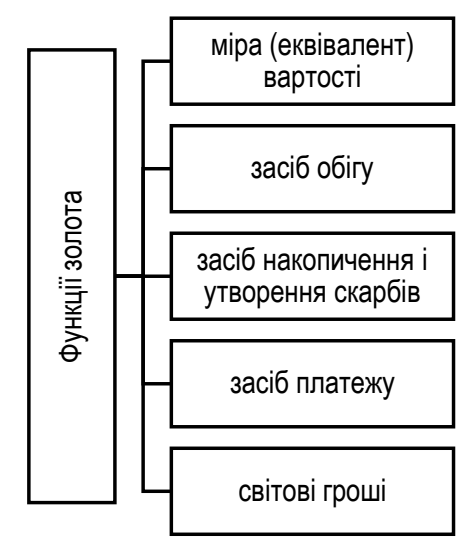

Джерело: побудовано автором.

Рис. 1. Функції золота у глобальній економіці.

Міра вартості видається очевидною, оскільки золото - матеріальна форма буття загального еквівалента [4, с. 115]. Вартість будь-якого товару вимірювалася золотом впродовж значного відрізку часу в історії людства. Однак, варто зазначити, що золото вправно виконує цю функцію - повноцінність золота не потрібно для визначення конкретної вартості даного товару.

Проте, технічна функція масштабу цін підтверджує думку про те, що саме золото справляється з цим завданням. В умовах золотого стандарту золото в першу чергу виконувало функцію міри вартості: міряло вартість усіх товарів. Вартість речі, виражена в грошах - його ціна. Для визначення ціни продуктів гроші не потрібні, оскільки продавець встановлює його корисність, яка знаходить своє вираження у загальному еквіваленті. Ціни товарів виражаються у відомій кількості грошового товару, золота. Кількість золота (його маса) вимірюється його вагою. Певну вагову кількість золота приймається за одиницю його маси. Ця одиниця, що встановлюється державою як грошова одиниця, називається масштабом цін. Масштаб цін і його кратні частини служать для виміру маси золота. Всі ціни товарів виражаються в певній кількості грошових одиниць, або, що одне і те ж, в певній кількості вагових одиниць золота.

Виконуючи функцію засобу обігу, золото фактично стає посередником в процесі обміну, який набирає вигляду товар-гроші-товар. Це означає, що вони швидкоплинно присутні в процесі звернення, переходячи з рук в руки, не перетворюючись при цьому в мету товарного обміну. Це дає підставу замінити їх в даному процесі якимось загальноприйнятим символом (знаком вартості). Правомірність цього підкріплюється і тим, що золоті злитки і монети в процесі переходу з рук в руки все-таки втрачають частину своєї маси, крім цього, існує і прагнення фальсифікувати золото, знизивши вміст благородного металу в злитках і монетах. Таким чином, були створені об'єктивні підстави для витіснення золота з безпосереднього процесу звернення, заміни його якимось визнаним знаком вартості. Спочатку це були монети, які карбували не з золота, але на них був присутній символ держави, яке емітувало їх в обіг. Після досить тривалої еволюції замінників повноцінних золотих грошей з'являються паперові гроші, які фрактично, будучи позбавленими внутрішньої вартості, виступають саме як знак вартості, який визнається всіма учасниками економічних відносин [5].

У функццї засобу обігу гроші виступають в якості посередника в обігу. В даному випадку гроші не затримуються довго в руках покупців та продавців і переходять з рук в руки, виконуючи розглянуту функцію швидкоплинно. Ця обставина дозволила, в кінцевому рахунку, замінити повноцінні гроші неповноцінними. В даний час, незважаючи на те, що золото як засіб звернення не має широкого ходіння, існує практика надання банком кредитів під заставу золота. Функція золота як засобу накопичення і утворення скарбів також представляється досить очевидною. У золоті, в його відносно невеликій кількості, концентрується велика кількість вартості, тому накопичення золота - це фактично накопичення вартості трансформації в будь-яку іншу форму цього багатства (нерухомість, земля, твори мистецтва та ін.). Практика «нових індустріальних драконів» і багатьох країн-членів ОПЕК показує: стабільність національної валюти може забезпечуватися товаром, який був і залишається інтернаціональним мірилом цінності - золотом. США в кінці 1960-х-початку 1970-х рр. надали масований тиск на міжнародні торговельні і фінансові організації, щоб де-факто примусити суб'єктів міжнародної торгівлі і світового фінансового ринку приймати в оплату виключно американські долари.

Функція грошей, як засобу накопичення багатства 3 усуненням золота з обігу характеризується новими характерними рисами. Скарби перестали виступати стихійним регулятором грошового обігу, оскільки золото не переходить автоматично з скарбів в обіг і назад через властивості нерозмінних кредитних грошей. Однак, дана функція зазнала зміни: її зв'язок зі світовим і внутрішнім ринками збережено, хоча і значно трансфрормовано. Скарби стали бути специфічним страховим фондом держави і приватних осіб. Зв'язок між приватною тезаврацією і процесами відтворення відзначається в трансформуванні частки капіталу в золото з метою збереження своєї фрактичної цінності на фоні інфляцції та валютної кризи.

Офіційні золоті запаси, зосереджені в світових центральних банках, фінансових органах різних країн і міжнародних валютно-кредитних організаціях, несуть в собі особливе значення як міжнародні авуари. Незважаючи на політику інтенсивної демонетизації жовтого металу, золотий запас США (8,133 тис. т) становить майже стільки, скільки у трьох інших держав, що мають найбільші офіційні запаси (Німеччини, Італії та Франції) (табл. 1). Обсяг золотого запасу виявляє валютно-фінансові позиції країни і служить індикатором ії кредитоспроможності. 
Найбільші власники офіційних золотих резервів станом на кінець другого кварталу 2018 р.

\begin{tabular}{|c|c|c|}
\hline $\begin{array}{l}\text { Країни та організації - власники золотих } \\
\text { резервів } \\
\end{array}$ & Кількість золота, тонн & $\begin{array}{c}\text { Частка золота в загальному обсязі національних } \\
\text { золотовалютних резервів (\%) }\end{array}$ \\
\hline США & 8133,5 & 74,1 \\
\hline Німеччина & 3369,9 & 69,6 \\
\hline MBФ & 2814,0 & - \\
\hline Італія & 2451,8 & 66,4 \\
\hline Франція & 2436,0 & 59,8 \\
\hline Російська Федерація & 1944,0 & 17,1 \\
\hline Китай & 1842,6 & 2,3 \\
\hline Швейцарія & 1040,0 & 5,2 \\
\hline Японія & 765,2 & 2,4 \\
\hline Нідерланди & 612.5 & 66,8 \\
\hline Індія & 566,2 & 5,6 \\
\hline Банк міжнародних розрахунків & 515,7 & - \\
\hline Європейський центральний банк & 504,8 & 26,5 \\
\hline Тайвань & 423,6 & 3,6 \\
\hline Португалія & 382,5 & 64,7 \\
\hline Узбекистан & 382,2 & 77,0 \\
\hline Саудівська Аравія & 323,1 & 2,5 \\
\hline Казахстан & 321,7 & 43,0 \\
\hline Великобританія & 310,3 & 8,0 \\
\hline Ліван & 286,6 & 20,4 \\
\hline
\end{tabular}

Джерело: побудовано автором на основі [6]

Основним власником золота (понад 80\% золотих резервів світу) є десятка провідних країн і фрінансових структур. Золоті резерви розподілені нерівномірно (в США-8 133,5 т, в Німеччині - 3 369,9 т, в Італії - 2 451,8 т, Франції - 2 436,0 т). Періодично відзначається їх перерозподіл у зв'язку зі зміною позиції держави в світовому виробництві та торгівлі.

Частка США в офріційних запасах золота набагато зменшилася у порівнянні із

1950 р. (20,3 тис. т) до тепер (8,1 тис. т), а країн Західної Європи, особливо Євросоюзу, збільшилася. Японія володіє незначними золотими резервами, які зросли з 3 до 754 т в 1948-1992 рр. і тримаються на цьому рівні. В Японії легалізовані як імпорт золота (в 1974 р.), так і його експорт (в 1978 р.), в 1982 р. був організований золотий ринок.

Стійким світовим явищем стало зберігання частки офіційних золотих резервів в міжнародних організаціях (в МВФ - 2,8 тис. т, Європейському центральному банку - близько 0,5 тис. Т). На частку понад 100 країн, що розвиваються припадає лише мала частина офріційних золотих резервів країн світу. В умовах підвищення цін на нафту з середини 1970-х рр. дещо зросли золоті запаси членів Організації країн
- експортерів нафтт, але останнім часом вони скоротилися. Більшість країн, що розвиваються мають малі золоті резерви $[33$, c. 80].

Світовий ринок золота в широкому плані охоплює всю систему циркуляції цього дорогоцінного металу у глобальній економіці - виробництво, розподіл, споживання. Іноді це поняття розглядається і в більш вузькому плані - як ринкового механізму, обслуговуючого куплю-продажу золота як товару на національних та міжнародному рівнях. При цьому слід мати на увазі, що, коли мова йде про основні особливості і параметрах ринків золота зазвичай мається на увазі, по-перше, купівля-продаж готівкового металу в злиткової формі і, по-друге, оптові методи торгівлі цими злитками.

Відповідно, особливості торгівлі так званим «паперовим золотом» аналізуються в рамках діяльності золотих бірж. Основним джерелом пропозиції золота на світовому ринку $є$ його виробники. Найбільшими золотодобувними державами є Китай, Австралія, США, ПАР, Перу і Канада. Росія закріпила за собою четверте місце у десятці провідних країн з видобутку золота у 2018 р. Динаміка виробництва золота по країнам представлена в таблиці 2.

Таблиця 2

Динаміка виробництва золота по країнам за період 2015-2017 рр.

\begin{tabular}{|l|c|c|c|c|c|c|c|}
\hline \multicolumn{1}{|c|}{ Країна } & \multicolumn{2}{c|}{ Видобуток золота, т. } & \multicolumn{2}{c|}{ Темп зростання, \% } & \multicolumn{2}{c|}{ Темп приросту, \% } \\
\hline & 2015 & 2016 & 2017 & $2016 / 2015$ & $2017 / 2016$ & $2016 / 2015$ & $2017 / 2016$ \\
\hline Китай & 460,3 & 463,7 & 429,4 & 1 & -7 & -99 & -107 \\
\hline Австралія & 279,2 & 287,7 & 292,5 & 3 & 2 & -97 & -98 \\
\hline США & 216,7 & 229,1 & 236,5 & 6 & 3 & -94 & -97 \\
\hline Російська Федерація & 255,3 & 262,4 & 280,7 & 3 & 7 & -97 & -93 \\
\hline ПАР & 162,0 & 162,6 & 154 & 0 & -5 & -100 & -105 \\
\hline Перу & 170,5 & 166,0 & 166,6 & -3 & 0 & -103 & -100 \\
\hline Канада & 157,7 & 163,1 & 171,2 & 3 & 5 & -97 & -95 \\
\hline Індонезія & 113,2 & 108,8 & 114,1 & -4 & 5 & -104 & -95 \\
\hline Узбекистан & 85,5 & 86,7 & 89,0 & 1 & 3 & -99 & -97 \\
\hline
\end{tabular}

Джерело: побудовано автором на основі [7]

За даними таблиці 2 ми бачимо, що лідером з видобутку жовтого металу є Китай, який стало нарощує обсяги видобутку золота. У короткостроковій перспективі (протягом 2- 
3 років) Китай планує збільшити видобуток до 500 тонн. До золотодобувним провінціях відносяться: Шаньдунь, Хенань, Цзянсі, Фуцзянь і Внутрішня Монголія. Тут видобуто близько $61 \%$ китайського золота. 3 великих компаній, що займаються видобутком жовтого металу, виділяються «China National Gold Group Corp.» i «Zijin Mining Group Co».

За підсумками 2017 року, на другому місці з даного показника знаходиться Австралія. Найбагатшими регіонами по знаходженню родовищ золота в країні є Західна Австралія, Південна Австралія і Новий Південний Уельс. Основні рудники Австралії - «Boddington», «Super Pit», «St. Ives»,
«Telfer». Якщо дивитися динаміку останніх років, то простежується певна стабільність, річні коливання не перевищують $5-10 \%$.

У ПАР є потенціал нарощування темпів видобутку жовтого металу, так як в країні є багато родовищ по всій території. До основних джерел видобутку золота в країні відносяться «Vaal River» і «West Wits». При розгляді загальної динаміки видобутку золота в світі за період 2016-2017 рр., можна простежити темпи зниження і нарощування видобутку золота, які представлені в таблиці 3. Найбільший спад спостерігається в ПАР і Китаї. Значне збільшення видобутку жовтого металу спостерігається в таких країнах як США, Росія і Канада.

Таблиия 3

Зміна видобутку золота з початку XXI століття у розрізі країн

\begin{tabular}{|l|c|c|c|}
\hline \multicolumn{1}{|c|}{ Країни (по величині зниження видобутку) } & \multicolumn{2}{|c|}{ Видобуток золота по роках, т } & 3міна видобутку, т \\
\hline & 2010 & 2017 & тонн \\
\hline ПАР & 210,0 & 154,0 & -56 \\
\hline США & 231,3 & 236,5 & 5,2 \\
\hline Канада & 102,1 & 236,5 & 34,4 \\
\hline Австралія & 256,7 & 292,5 & $-20,5$ \\
\hline Індонезія & 134,6 & 114,1 & 18 \\
\hline Узбекистан & 71,0 & 89,0 & $-5,4$ \\
\hline Папуа Нова Гвінея & 69,7 & 64,3 & 35,9 \\
\hline Гана & 94,3 & 130,2 & $-18,2$ \\
\hline Перу & 184,8 & 166,6 & 40,6 \\
\hline Мексика & 78,8 & 119,4 & \\
\hline
\end{tabular}

Джерело: побудовано автором на основі [8]

Стабільно високий рівень видобутку зберігає Австралія (292,5 т). Родовища золота зустрічаються по всій країні, однак найбільш багатими регіонами є Західна Австралія, Південна Австралія і Новий Південний Уельс. Найбільші родовища Австралії - «Boddington» (21 т), «Super Pit» (21,5 т), «St. Ives »(14,5 T), « Telfer »(20 T).

Наближений до Австралії обсяг видобутку золота в 2017 р. продемонстрували США (236,5 т). В останнє десятиліття виробництво золота в США відрізняється стабільністю, річні коливання виробництва золота не перевищують 5-10\%. В цілому простежується тенденція зростання виробництва золота (231,3 т в 2010 р і 236,6 т в 2017 р). Велика частина золота в США (близько 75\%) добувається в штаті Невада на 3-х найбільших рудниках (29, 35 і 36 т); близько 30 т добувається на Алясці.

У ПАР протягом багатьох років видобуток золота систематично скорочується. У 2015 р. ПАР поступилася першим місцем по виробництву золота в світі Китаю, яке утримувала більше 100 років (з 1896 р). Причини зниження видобутку золота пояснюють неоднозначно: збільшенням глибини відпрацювання запасів, політичною нестабільністю, страйковим рухом на шахтах, спробою зберегти запаси золота з урахуванням очікуваного зростання ціни та ін. ПАР володіє найбільшими в світі запасами золота і має можливість збільшення видобутку золота. Найбільші родовища в ПАР - «Vaal River» (23,5 т), «West Wits» (22,5 т).

\section{Висновки}

Перспективи ринку золота оцінюються позитивно, але останнім часом, можна зробити висновок про помітне зниження інтересу до дорогоцінних металів. Посилення схильності інвесторів до ризику і ростуть разом з цим фондові індекси істотно скоротили інвестиційний попит на золото, який на поточний момент є одним з головних факторів, що визначають динаміку котирувань жовтого металу. Таким чином, особливостями ринку золота проявляється в тому, що, по-перше, благородний метал використовується практично всіма країнами в якості страхового і резервного фонду. Враховані державні резерви жовтого металу, зосереджені в Центральному Банку і резервах МВФ, дорівнюють більш 31000 т. По-друге, ще більші обсяги даного металу є у населення.

Провідним споживачем готівкового благородного металу є ювелірна промисловість, попит в якій більшою мірою визначається ціною дорогоцінного металу: чим нижча ціна, тим більший попит. Проте, задана закономірність працює в періоди всесвітнього економічного підйому, а в періоди спаду попит у ювелірній промисловості зменшується при відносно низьких цінах.

Що стосується перспектив, то на початку року ще занадто рано говорити про перспективи споживання золота в 2018 році. Втім, скорочення виробництва, враховуючи заявлене скорочення пропозиції і нове зниження виробництва гірничодобувними компаніями, наддасть підтримку цінам в майбутньому. Ще в 2015 році гірничодобувні компанії скорочували свої витрати і бюджети на розвідку і освоєння родовищ і це послужило тому, що очікувана кількість нових рудників насправді невелика. В цілому, розвиток золотодобувної галузі відбувається циклічно. Загальний рівень видобувається в світі золота істотно не змінюється. Тим не менш, з урахуванням значного зростання рівня видобутку золота в Китаї, який спостерігається в останні роки, експерти з упевненістю говорять про перспективи істотного збільшення обсягів щорічного світового видобутку золота.

\section{Список літератури:}

1. Grimal, Pierre (1991). The Penguin dictionary of classical mythology. Kershaw, Stephen. (Abridged) ed. London: Penguin 
Books.

2. J. Cargill, "The Nabonidus chronicle and the fall of Lydia: Consensus with feet of clay", American Journal of Ancient History $2(1977: 97-116)$

3. Mikesell, R. F. (1994). The Bretton Woods Debates: A Memoir. Essays in International Finance 192. Princeton: International Finance Section, Dept. of Economics, Princeton University.

4. Фінансово-економічний словник: словник-довідник / кол. авт.: Юнін О. С., Круглова О. О., Савєльєва М. О. та ін. Дніпро : Видавець Біла К. О., 2018. 164 с.

5. Obiri, S., Mattah, P., Mattah, M., Armah, F., Osae, S., Adu-Kumi, S., \& Yeboah, P. (2018). Assessing the environmental and socio-economic impacts of artisanal gold mining on the livelihoods of communities in the Tarkwa Nsuaem municipality in Ghana. International journal of environmental research and public health, 13(2), 160.

6. Quarterly times series on World Official Gold Reserves since 2000. World Gold Council., 2018. URL: https://www.gold.org/download/file/8052/quarterly_gold_and_fx_reserves_q2_2019.xlsx

7. World Gold Council / «Supply and Demand», "Gold mine production». London, 2018. URL: https://www.gold.org/download/file/7593/Gold-Mining-Production-Volumes-Data.Xlsx

8. Kamga, M. A., Olatubara, C. O., Atteh, M. M., Nzali, S., Adenikinju, A., Mbiatso, T. Y., \& Ngatcha, R. B. (2018). Perception of the environmental degradation of gold mining on socio-economic variables in Eastern Cameroon, Cameroon. European Journal of Sustainable Development Research, 2(2), 23.

Ksenzhuk O. S., Ternopil National Economic University (Ternopil, Ukraine)

Retrospective analysis and perspectivies of gold market functioning

The article describes the role of gold in the historical perspective and nowadays. Gold has lost the role of money and become a commodity. The physicochemical properties of gold cause a consistently high level of investment attractiveness. The dynamics of the development of the gold market over the last decades has been shown to show an upward trend. The share of developing countries in shaping global demand for gold is constantly increasing.

The reason for giving gold a priority as a means of accumulating and storing value is the increasing riskiness of the global economic landscape given the increasing interdependence of countries as a result of globalization processes. The jewelry industry is showing increasing demand for jewelry goods. Increasing demand for gold as a tool for hedging and preserving value, as well as the development of the jewelry industry, determine the upward trends in gold production, and therefore the development of the gold market.

The leading consumer of cash precious metal is the jewelry industry, the demand to which is more determined by the price of the precious metal: the lower the price, the greater the demand. However, a given pattern works during periods of global economic recovery, and during periods of recession, demand in the jewelry industry decreases at relatively low prices.

Gold has undergone a long evolution, repeatedly changing its functions and role in the world economy, however, at all stages of the development of civilization, this role remained high. Gold is an essential element of the world financial system, as this metal is not susceptible to corrosion, has many applications, and its reserves are small. In all times of the world economic system, gold has been an integral part of economic relations. In modern conditions, gold has ceased to be the basis of monetary circulation, but it is an integral part of the country's foreign exchange reserves.

In general, the development of the gold industry is cyclical. The overall level of gold produced in the world does not change significantly. However, given the significant increase in gold production in China that has been observed in recent years, there is a high probability of a significant increase in annual global gold production taking place.

Keywords: gold market, investment appeal, gold reserves, gold mining, precious metals

Дата надходження до редакції: 13.02 .2019 р. 